\title{
Spontaneous pneumomediastinum in an 18-year-old woman: the importance of excluding oesophageal perforation
}

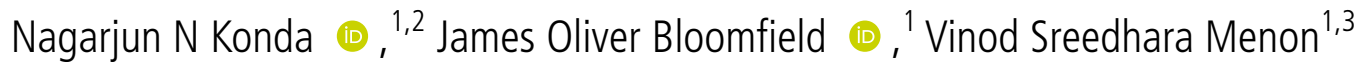

'Department of Upper Gastrointestinal Surgery, University Hospitals Coventry and Warwickshire NHS Trust, Coventry, UK

${ }^{2}$ Clinical Trials Unit, University of Warwick, Coventry, UK ${ }^{3}$ School of Medicine, University of Warwick, Coventry, UK

\section{Correspondence to} Dr Nagarjun N Konda; nagarjun.konda1@nhs.net

Accepted 26 March 2021
Check for updates

(c) BMJ Publishing Group Limited 2021. No commercial re-use. See rights and permissions. Published by BMJ.

\begin{tabular}{|l|}
\hline To cite: Konda NN, \\
Bloomfield JO, \\
Menon VS. BMJ Case \\
Rep 2021:14:e243041. \\
doi:10.1136/bcr-2021- \\
243041 \\
\hline
\end{tabular}

\section{DESCRIPTION}

An 18-year-old woman presented to the emergency department with a 3-day history of vomiting, central abdominal pain and decreased oral intake. She described frequent episodes of bilious vomit without haematemesis. She denied previous alcohol or illicit drug use, smoking or recent travel. There was no significant medical history. On examination, the abdomen was soft, with epigastric tenderness on palpation, without guarding or peritonism. Palpation of the clavicular fossae and neck revealed extensive surgical emphysema. Her observations were stable apart from a tachycardia (heart rate 104). Her admission bloods showed a white cell count $20.3 \times 10^{9} / \mathrm{L}(4-11)$, neutrophils $16.9 \times 10^{9} / \mathrm{L}$ (2-7), CRP 8, lactate of $3.4 \mathrm{mmol} / \mathrm{L}$ and a stage 3 acute kidney injury: urea $37.6 \mathrm{mmol} / \mathrm{L}$ (2.5-7.8), creatinine $338 \mu \mathrm{mol} / \mathrm{L}$ (50-90). A SARS-CoV-2 PCR swab was negative. Due to clinical suspicion of an oesophageal perforation, her care was referred to the upper gastrointestinal surgical team.

A CT scan of the neck, thorax, abdomen and pelvis (figure 1) revealed bilateral apical pneumothoraces measuring $14 \mathrm{~mm}$ and $10 \mathrm{~mm}$ in the right and left lung, respectively. It also demonstrated pneumomediastinum and surgical emphysema tracking from the base of the skull, down both arms, into the chest, abdominal wall and retroperitoneal space. The abdominal organs were reported as radiologically normal and no free gas was visualised within the intraperitoneal space.

An oesophago-gastro-duodenoscopy (OGD) was performed (figure 2) to exclude an oesophageal perforation. The OGD showed Los Angeles Grade D oesophagitis (mucosal breaks involving $\geq 75 \%$ of mucosal circumference) and oesophageal congestion, but no mucosal tear was identified. A watersoluble contrast swallow (WSCS) was requested (video 1), which did not demonstrate any evidence of a contrast leak.

Initial management included intravenous fluids, analgesia, high dose intravenous proton pumpinhibitor therapy, broad-spectrum intravenous antibiotics and antifungals. Following the OGD and WSCS, her oral intake was slowly built up and she made a full recovery. An outpatient high-resolution CT scan was performed 6 weeks post-discharge. This revealed complete resolution of the pneumothoraces, pneumomediastinum and surgical emphysema. No underlying lung pathology was identified.

Spontaneous pneumomediastinum is rare, characterised by air leaking into the mediastinum,

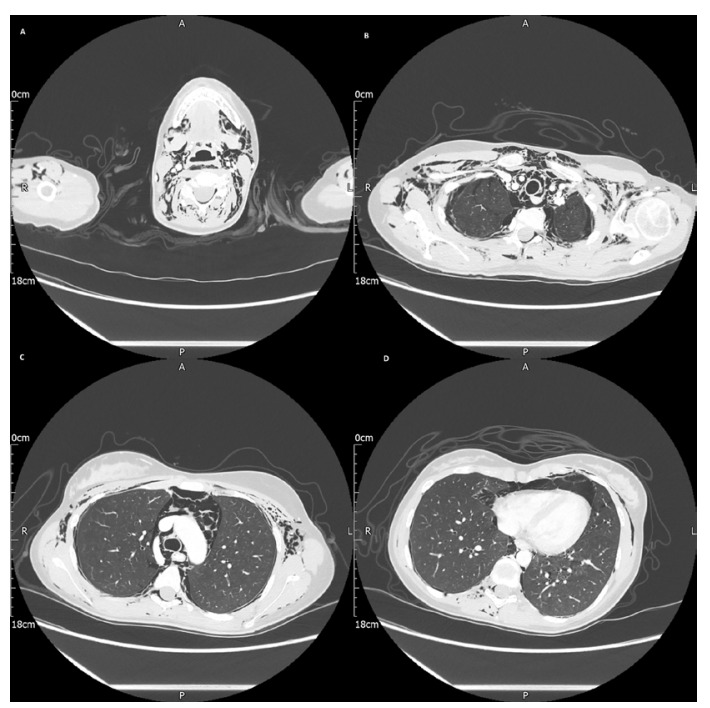

Figure 1 (A) Extensive surgical emphysema tracking from the level of the base of skull (B) bilateral pneumothoraces measuring up to $14 \mathrm{~mm}$ in the right lung apex, and $10 \mathrm{~mm}$ in the left apex (C) normal calibre and morphology of the thoracic aorta and the major branches (D) extensive pneumomediastinum.

occurring in only $0.01 \%-0.001 \%$ of hospital cases. ${ }^{1}$ Most cases of pneumomediastinum are caused by underlying lung disease, infections, mechanical ventilation (barotrauma) or connective tissue disorders. Although rarer associations with illicit drug use, particularly intravenous drug use, the smoking of cocaine and even infection with COVID-19 have been reported. ${ }^{2-4}$ An important differential to exclude in spontaneous pneumomediastinum is Boerhaave's syndrome, defined by spontaneous oesophageal perforation in the absence of an existing oesophageal pathology. ${ }^{2} 3$ Boerhaave's syndrome classically presents with Mackler's triad

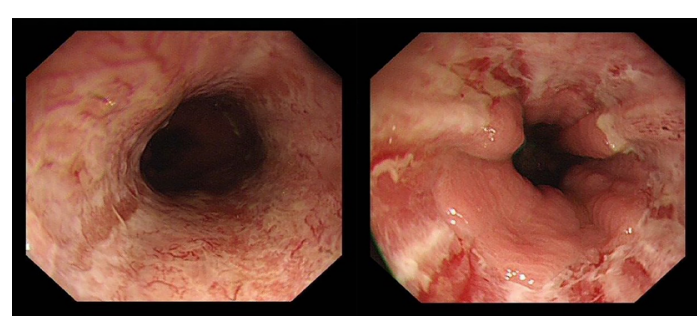

Figure 2 Oesophago-gastro-duodenoscopy with Grade $\mathrm{D}$ oesophagitis in multiple oesophageal anatomical locations. 


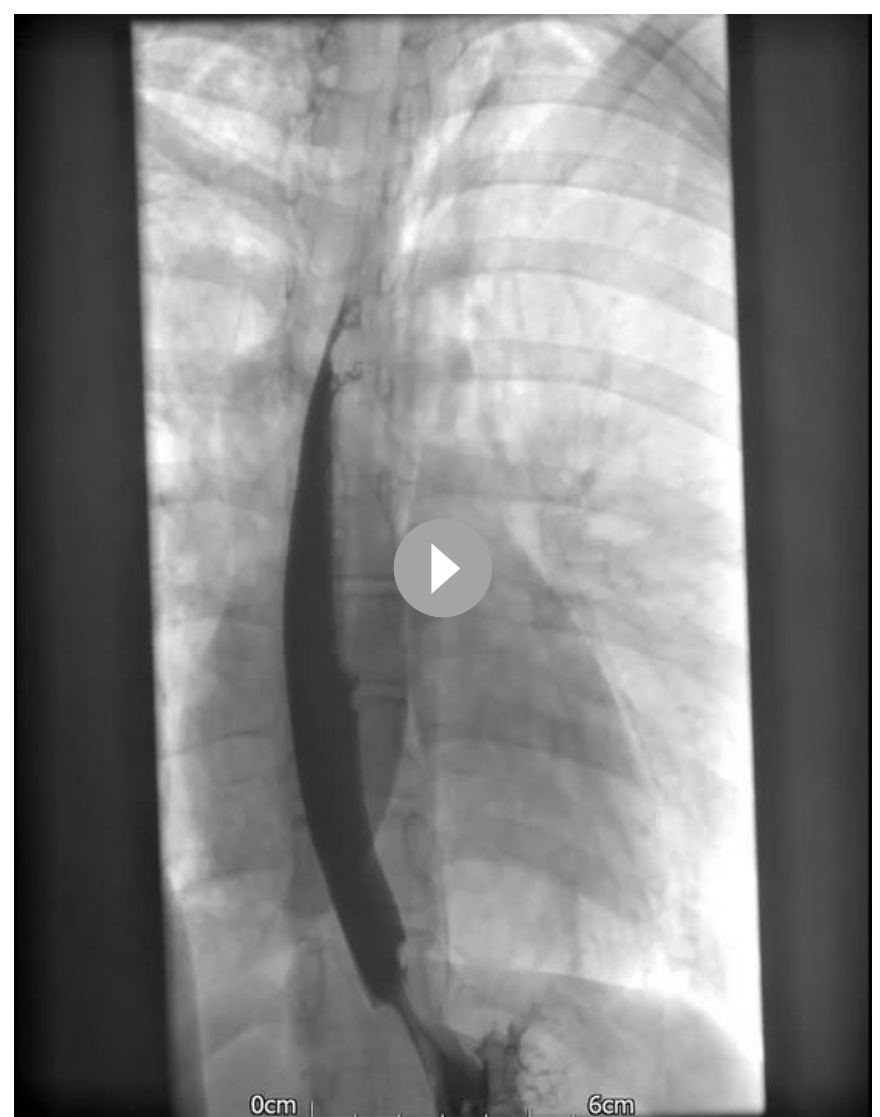

Video 1 Water soluble contrast swallow demonstrating no evidence of contrast extravasation suggesting a mucosal tear.

of severe vomiting, chest pain and subcutaneous emphysema, however, it can present in a variety of ways and often presents atypically. ${ }^{5}$ Although uncommon, it warrants a high index of suspicion due to mortality rates of between $10 \%$ and $40 \%$, and up to $60 \%-70 \%$ of cases in post-emetic oesophageal perforation. ${ }^{67}$ Patients with suspected oesophageal perforations should be extensively investigated with radiology and endoscopy with careful consideration of fluoroscopy.

\section{Learning points}

- A comprehensive history including foreign travel, alcohol use and illicit drug use must be ascertained especially in younger patients with no history of respiratory disease.

- Spontaneous pneumomediastinum and pneumothorax should be investigated with CT and endoscopy, as well as careful consideration of fluoroscopy to exclude oesophageal perforation.

- Follow-up imaging with high-resolution CT should be considered in cases where no obvious cause has been found to identify underlying lung pathology.

Contributors NNK and JOB produced the manuscript, obtained patient consent and the radiological images. VSM revised the manuscript.

Funding The authors have not declared a specific grant for this research from any funding agency in the public, commercial or not-for-profit sectors.

Competing interests None declared.

Patient consent for publication Obtained.

Provenance and peer review Not commissioned; externally peer reviewed.

\section{ORCID iDs}

Nagarjun N Konda http://orcid.org/0000-0002-8801-1278

James Oliver Bloomfield http://orcid.org/0000-0002-9816-5123

\section{REFERENCES}

1 Takada K, Matsumoto S, Hiramatsu T, et al. Spontaneous pneumomediastinum: an algorithm for diagnosis and management. Ther Adv Respir Dis 2009;3:301-7.

2 Rampuri R, Ali Y, Verkerk M, et al. Unusual cause of pneumomediastinum. BMJ Case Rep 2018;74:bcr2018224343.

3 Mohan V, Tauseen RA. Spontaneous pneumomediastinum in COVID-19. BMJ Case Rep 2020;13:e236519.

4 Ciriaco P, Rossetti F, Carretta A, et al. Spontaneous pneumothorax in cocaine users. QJM 2019;112:519-22.

5 Garas G, Zarogoulidis P, Efthymiou A, et al. Spontaneous esophageal rupture as the underlying cause of pneumothorax: early recognition is crucial. J Thorac Dis 2014;6:1655-8.

6 Nirula R. Esophageal perforation. Surg Clin North Am 2014;94:35-41.

7 Kaman L, Iqbal J, Kundil B, et al. Management of esophageal perforation in adults. Gastroenterology Res 2010;3:235-44.

Copyright 2021 BMJ Publishing Group. All rights reserved. For permission to reuse any of this content visit

https://www.bmj.com/company/products-services/rights-and-licensing/permissions/

BMJ Case Report Fellows may re-use this article for personal use and teaching without any further permission.

Become a Fellow of BMJ Case Reports today and you can:

- Submit as many cases as you like

- Enjoy fast sympathetic peer review and rapid publication of accepted articles

- Access all the published articles

- Re-use any of the published material for personal use and teaching without further permission

Customer Service

If you have any further queries about your subscription, please contact our customer services team on +44 (0) 2071111105 or via email at support@bmj.com.

Visit casereports.bmj.com for more articles like this and to become a Fellow 